\title{
Article
}

|||||||||||||||||||||||||||||||||||||||||||

\section{Autoradiography of Lyophilized Animal Sections : Bone Density Measurement in Osteoporosis Model Rats}

\author{
Hideki Fujino, Nobumitsu Asahara * Hideki Kimata **, \\ Mitsuru TAteISHI **, Takashi KoIDE** and Shigeo $\mathrm{B}_{\mathrm{ABA}}^{*, * * *}$ \\ Graduate School of Advanced Science and Engineering, Waseda University \\ 1011-3 Nishitomita ohkuboyama, Honjo-shi, Saitama Pref. 367-0035, Japan \\ * Tsukuba Laboratories, Nemoto Science Co. Ltd. \\ 6136-4 Ohnogoumachi, Jyousou-shi, Ibaraki Pref. 300-2521, Japan \\ **Tokyo New Drug Research Laboratories, KOWA Co. Ltd. \\ 2-17-43 Noguchi-cho, Higashimurayama-shi, Tokyo 189-0022, Japan \\ *** Tokyo University of Pharmacy and Life Science \\ 1432-1 Horinouchi, Hachiohji-shi, Tokyo 192-0392, Japan
}

Received August 30, 2007

\begin{abstract}
To gain a better understanding on the $\beta$-ray radiography of lyophilized animal sections, the bone densities of the osteoporosis rats were measured using $a^{147} \mathrm{Pm}$ planar radiation source. An imaging plate as a radiation sensor was overlaid on the animal section together with a density calibrator. After exposure, radioactivity recorded on the sensor was quantified using a bio-imaging analyzer. The density calibration curve showed linearity in the wide range with a good correlation coefficient $\left(R^{2} \geqq 0.999\right)$. The inter-and intra-plate variability showed $C V$ values less than $3.7 \%$. On the measurement of bone density, bone density differences between the sham group and ovariectomized $(\mathrm{OVX})$ group were statistically significant in the femoral cortical $(p=0.001)$ and trabecular bone $(p=0.07)$, and vertebral trabecular bone $(p=0.043)$. Based on these results, we developed a new and valuable method, which made it possible to measure bone density of axial skeleton of a rat, as an alternative to commonly used methods.
\end{abstract}

Key Words : osteoporosis, bone density, ovariectomized rat, autoradiography, promethium-147

\section{Introduction}

With the growing aged population, osteoporosis is accepted as one of the most important factor with regard to reducing the quality of life and increasing the social cost ${ }^{1}$. Postmenopausal bone loss is mainly due to the loss of gonadal functions. For example, estrogen affects the bones acting directly on its related receptors, which are located on osteoblasts and osteoclasts ${ }^{2}$. An ovariectomized (OVX) rat is considered a good animal model of postmenopausal osteoporosis and has become a very popular model to investigate the effect of estrogen deficiency on the metabolism of bones at various skeletal sites ${ }^{3), 4)}$. Also, OVX rats can serve as an animal model to investigate the effects of therapeutic agents on bone mass, structure and turnover ${ }^{5}$. Using this model, several pharmaceutical compounds were screened and found to be effective for the therapeutic management of osteoporosis, namely, estrogen, bisphosphonate, calcitonin, calcium products and anabolic steroids ${ }^{6)-8)}$.

Obtaining early information on tissue distribution is critical for evaluation of new drug 
candidates. Whole-body autoradiography (WBA) is widely applied to examine the distribution of labeled compounds in experimental animals $^{9)}$. On the other hand, it past almost 20 years since Bio-imaging analyzing system (BAS), phosphor scanner with imaging plate was brought to the field of $\mathrm{WBA}^{10)}$. These systems have been used by many scientists for various researches ${ }^{11)-13)}$. In particular, quantitative WBA (QWBA), a method of quantifying levels of drug-related radioactivity in tissues by exposing radioactive histological sections to phosphor detection plates and using BAS systems for quantification, has been accepted as a principal tool for this purpose and becoming more widely used ${ }^{14)}$. QWBA has several advantages of time saving, decrease in number of animals for experiments, budget reduction for marketing any efficacious drugs, over BAS system.

Recently, Baba et al. reported a new radiographic method using the QWBA system that gives radiographic images of density distribution of lyophilized animal sections ${ }^{15), 16}$. This new method involves sandwiching the animal section in the space between an imaging plate as a radiation sensor and a ${ }^{147} \mathrm{Pm}$ planar radiation source. We also designed a new method of the bone density measurement using this method. In the current study, we measured densities of the several bones in both sham rats and OVX rat by $\beta$-ray radiography.

\section{Materials and Methods}

$2 \cdot 1$ Materials

A ${ }^{147} \mathrm{Pm}$ planar radiation source with $100 \mathrm{mg}$ / $\mathrm{cm}^{2}$ in density was prepared by uniformly spreading approximately $0.4 \mathrm{GBq}$ of ${ }^{147} \mathrm{Pm}$-promethium oxide, combined with an organic binder on a $20 \times 40 \mathrm{~cm}$ plastic plate, drying the plate in air and wrapping it in a sheet of plastic film of $1.8 \mathrm{mg} / \mathrm{cm}^{2}$ in density. All other solvents and chemicals were obtained commercially, and were of HPLC grade or extra pure grade.

\section{$2 \cdot 2$ Animals}

Wistar strain (specific pathogen-free) twelve female rats at nine weeks of age, weighing about $200 \mathrm{~g}$ were purchased from Japan laboratory animal Inc (Shizuoka, Japan). According to a previous report ${ }^{17)}$, the operative procedure for ovariectomy was investigated as follows. The hair of the operative area of the twelve rats anesthetized with pentobarbital was shaved and painted with $70 \%$ ethanol as a skin disinfectant. A dorsal midline incision was made through the skin at the level of the kidney. The ovaries exposed through the thin muscle wall by retracting the skin laterally toward either side were pulled into the incision and excised after the ligation of the upper horn of the uterus. The wounds were closed with surgical clips and painted with a tincture of iodine. The procedure for ovariectomy was performed in six rats. The six remainders were subjected to sham surgeries as follows. The sham operation was performed in the same procedure as the ovariectomy except the ligation of the upper horn of the uterus. The excision of the ovaries were left undone before the closure of the incision. All animals were housed in an environmentally-controlled room and kept on a $12 \mathrm{~h}$ light-dark cycle at $23 \pm 2{ }^{\circ} \mathrm{C}$ and were maintained on laboratory chow diets ( $\mathrm{CE}^{-}$ 2, Japan CLEA). The OVX rats and control rats at 18 weeks of age were sacrificed by ether inhalation 60 days after ovariectomy. All procedures were in accordance with the guidelines on animal experiments and the study was ap- 


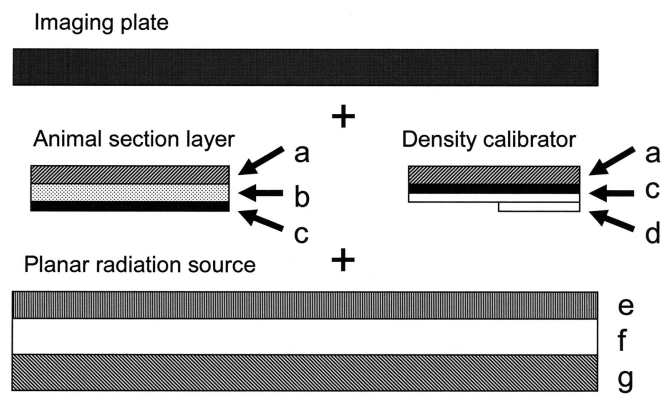

Fig. 1 Proposed system of $\beta$-ray radiography.

a) adhesive tape ; b) animal section;c) thin plastic film ; d) aluminum foil ; e) plastic film ; f) ${ }^{147} \mathrm{Pm}$ layer;g) plastic plate

proved by the institutional use and care of the animal committee of Kowa Co. Ltd.

\section{$2 \cdot 3$ Preparation of section}

A section of a rat was prepared by the conventional method $^{7), 13)}$. Namely, a rat was immediately frozen in ice-hexane mixture. The frozen carcass was then embedded in $5 \%$ carboxymethycellulose (CMC) solution on a microtome stage, held in a JUNG-CRYOMACROCUT (CM-3600, Leica Microsystems GmbH) and cut into about $50 \mu \mathrm{m}$ slices at $-20{ }^{\circ} \mathrm{C}$. The obtained sections were caught on tape and lyophilized at one overnight. The surfaces of these slices were covered with a sheet of protective film with $4 \mu \mathrm{m}$ in thickness.

\section{$2 \cdot 4 \quad \beta$-ray radiography}

Figure 1 shows the system used in this study of $\beta$-ray radiography when applied to a rat section examined. A density calibrator was prepared by overlaying a sheet of aluminum foil with $18.8 \mu \mathrm{g} / \mathrm{mm}^{2}$ in density. An imaging plate (IP) was overlaid on the animal section and density calibrator, having them stand in line. These samples were superimposed on the ${ }^{147} \mathrm{Pm}$ planar radiation source for 30 minutes. After exposure, the radioactivity recorded on the IP was quantified using a bioimaging analyzer (BAS system, FUJIFILM).

\section{$2 \cdot 5$ Assay validation}

The validation studies of intra-section and inter-section variation were performed for the density analysis using lyophilized section of lead acetate. The preparation of lead acetate analytes and the measurements of the density were carried out with the same manner as the rat preparation's. The variation of intra-section assay was performed by the analysis of the four sections. Inter-section assay was evaluated by analysis of the upper, middle and lower layer at the same section.

\section{$2 \cdot 6$ Calculation}

Bone density was measured by structuring the region of interest (ROI) area on the bone image, and calculated from the calibration curve of density calibrator. Data are expressed as the mean \pm S.D. of the control and OVX groups. Significant differences between the two groups were evaluated with the Student's $t$-test. $\mathrm{P}$ values less than 0.05 were considered significant.

\section{Results}

\section{$3 \cdot 1$ Calibration curve and validation study}

Figure 2 shows the calibration curve of the aluminum density. Also, Fig. 3 (D) shows the $\beta$-ray radiography of density calibrator using the overlaid aluminum foil. The linearity between PSL (Photo-Stimulated Luminescence) and density is evaluated in the range of 18.8 to $94 \mu \mathrm{g} / \mathrm{mm}^{2}$ of aluminum. The equation of density calibration curve was Log PSL $=-0.0071$ $\times$ density +2.378 and the correlation coefficient is 0.999 . The inter- or intra-section variability of density is summarized in Table 1 . The lead 


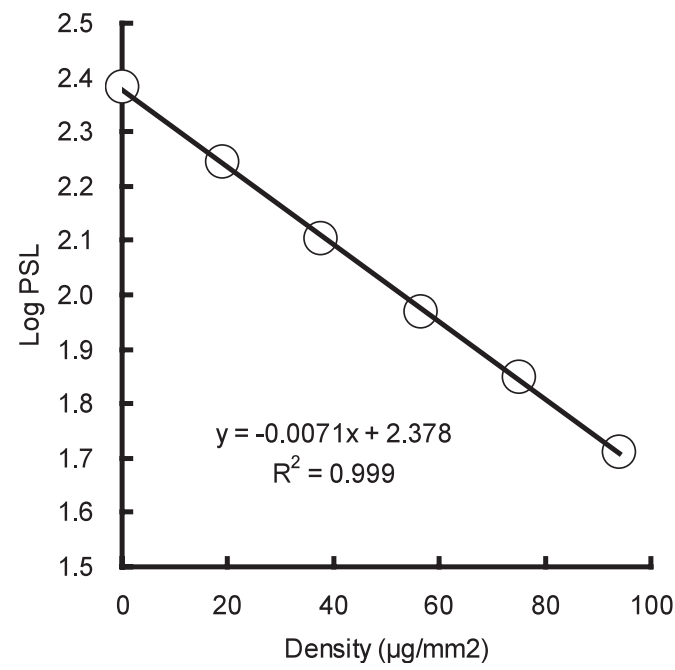

Fig. 2 Calibration curve of aluminum density.

densities for the inter-section and intra-section had CV values less than $3.7 \%$. In addition, no marked difference was observed between the three quantified sites of section.

$3 \cdot 2$ Bone density measurement of sham and OVX rats

The increase in body weight of the OVX rats was significantly higher than in the sham rats (data not shown). The mean body weights $\pm \mathrm{SD}$ were $289 \pm 10 \mathrm{~g}$ in the sham rats and $354 \pm 14 \mathrm{~g}$ in the OVX rats 60 days after operation.

Figure 3 shows the representative $\beta$-ray radiography of animal sections of the sham rat. In the current study, the subjects of bone density measurement were the femur, pelvic bone and vertebral column of rats, respectively. Also, the region of interest (ROI) was created on the femoral cortical bone, spongy bone, marrow, and vertebral whole body, trabecular bone, and pelvic cortical bone in the sham rats and OVX rats, respectively.

In the measurement of the femur, the densities of cortical bone, spongy bone, and bone marrow were $60 \pm 3 \mu \mathrm{g} / \mathrm{mm}^{2}, 44 \pm 2 \mu \mathrm{g} / \mathrm{mm}^{2}$ and $17 \pm 2 \mu \mathrm{g} / \mathrm{mm}^{2}$ in the sham group, and $45 \pm$ $5 \mu \mathrm{g} / \mathrm{mm}^{2}, \quad 38 \pm 3 \mu \mathrm{g} / \mathrm{mm}^{2}, \quad 18 \pm 3 \mu \mathrm{g} / \mathrm{mm}^{2}$ in the OVX group (Fig. 4). The cortical and spongy bone density in the OVX group decreased up to $75 \%$ and $80 \%$, respectively, comparing with those in the sham group. The difference was statistically significant (cortical bone : $\mathrm{P}=0.001$, spongy bone : $\mathrm{P}=0.007$ ).

As for the measurement of vertebral column, whole body and trabecular density were $46 \pm 5$ $\mu \mathrm{g} / \mathrm{mm}^{2}$ and $42 \pm 3 \mu \mathrm{g} / \mathrm{mm}^{2}$ in the sham group, and $44 \pm 5 \mu \mathrm{g} / \mathrm{mm}^{2}$ and $35 \pm 3 \mu \mathrm{g} / \mathrm{mm}^{2}$ in the

Table 1 Inter-section and intra-section variability of the $\beta$-radiography

\begin{tabular}{cllll}
\hline \hline Site & $\begin{array}{l}\text { Mean density } \\
\text { of lead }\end{array}$ & S.D. & $\begin{array}{l}\text { C.V. } \\
(\%)\end{array}$ \\
\hline Inter-section* $^{*}$ & Upper & 43.1 & 1.4 & 3.2 \\
& Middle & 43.7 & 1.6 & 3.7 \\
& Lower & 44.3 & 1.4 & 3.2 \\
\hline Intra-section** $^{*}$ Upper & 42.8 & 1.3 & 3.1 \\
& Middle & 42.1 & 1.4 & 3.2 \\
& Lower & 43.2 & 1.4 & 3.2
\end{tabular}

\footnotetext{
* Four different samples were analyzed by radiography four times on the same day. ** Four different samples (each $n=4$ ) were analyzed by radiography three times.
} 
(A)
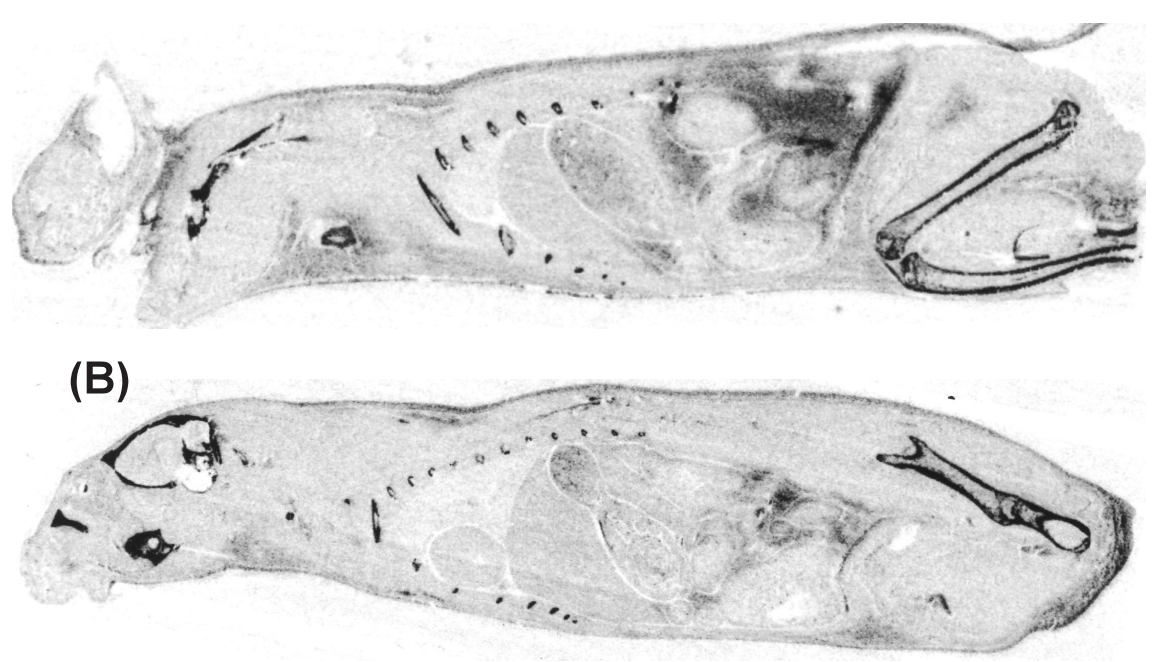

(C)

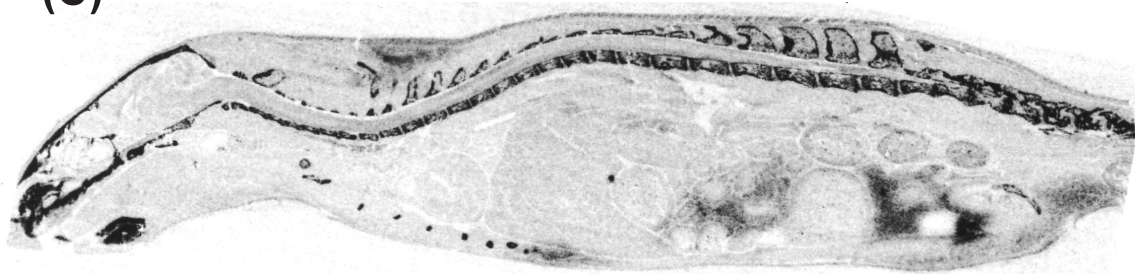

(D)

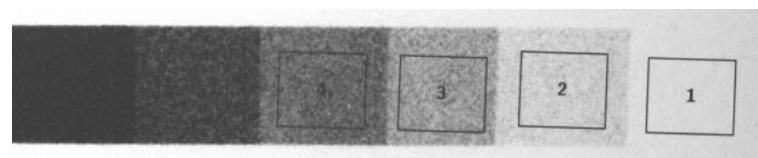

$94 \mu \mathrm{g} / \mathrm{mm}^{2} \quad 75.2 \mu \mathrm{g} / \mathrm{mm}^{2} \quad 56.4 \mu \mathrm{g} / \mathrm{mm}^{2} \quad 37.6 \mu \mathrm{g} / \mathrm{mm}^{2} \quad 18.8 \mu \mathrm{g} / \mathrm{mm}^{2} \quad 0 \mu \mathrm{g} / \mathrm{mm}^{2}$

Fig. $3{ }^{147} \mathrm{Pm} \beta$-ray radiography of rat femur (A), pelvic bone (B), vertebral column $(\mathrm{C})$ and density calibrator $(\mathrm{D})$.

OVX group (Fig. 5). A statistically significant difference was observed in the vertebral trabecular bone density measurement between the two group ( $\mathrm{P}=0.043)$. However, there was not statistically significant difference in the vertebral whole body and pelvic bone density measurement between the two groups (data not shown).

\section{Discussion}

To confirm the effects in a rat model for os- teoporosis, we used OVX rats because they represent an animal model of ovarian hormone deficiency in postmenopausal women ${ }^{2)-4}$. Reportedly, several clinical studies suggested that increased bone turn-over occurs during the early stages of estrogen deficiency ${ }^{18)}$. Furthermore, ovarian hormone deficiency causes the several impairment factors for development of osteoporosis. Women with postmenopausal osteoporosis often have impaired calcium absorption $^{19)}$. While several papers described the ef- 


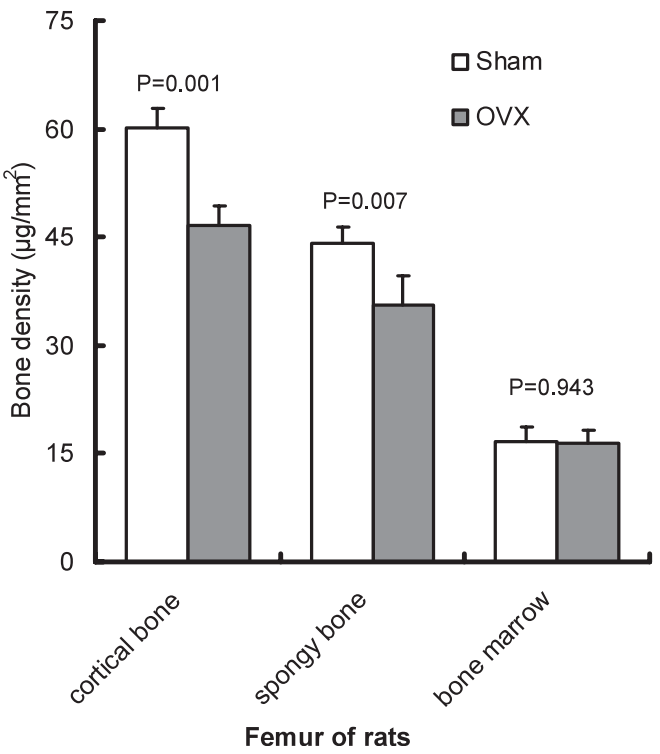

Fig. 4 Bone density measurement of sham and OVX rats femur by ${ }^{147} \mathrm{Pm}$ radiography.

Each result represents mean \pm S.D. of six rats.

fects of absorption in OVX animals, the effects do not necessarily agree with those observed in patients with osteoporosis ${ }^{20), 21)}$. Recently, Kobayashi et al. reported that the rationale for such contradictory findings was associated with the age of rats ${ }^{22}$. In our series, we decided to measure the bone density of all rats at 60 days after surgery. We created the ROIs on each of femur, vertebral column and pelvic bone in both sham rat group and OVX rat group, and measured bone density in each ROI. The decrease in bone density was not uniform and the bone marrow of the femur showed no statistically significant difference between the sham group and the OVX group. In case of the vertebral column, the density of the vertebral body showed no difference between both groups. However, there was a statistically significant difference between the two groups in the trabecular bone of the vertebral column. These results suggested that bone turnover impairment depends on time after ovariectomy

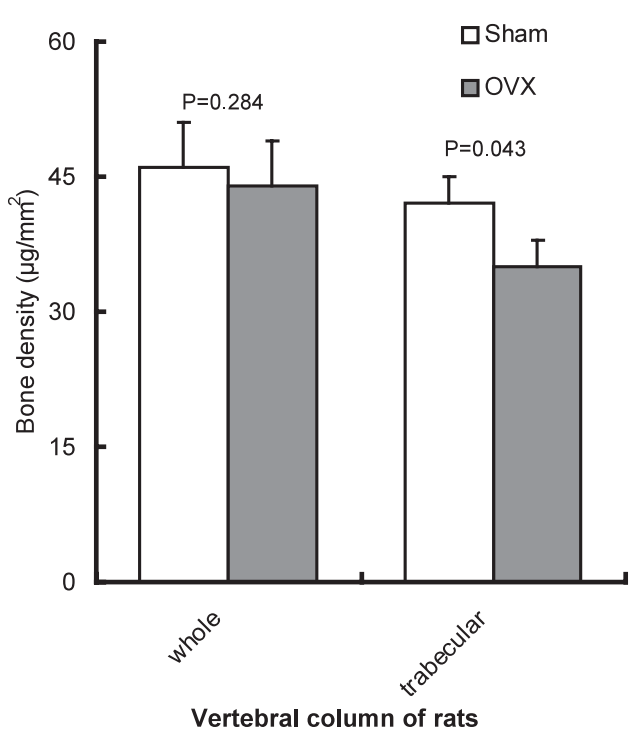

Fig. 5 Bone density measurement of sham and OVX rats vertebral column by ${ }^{147} \mathrm{Pm}$ radiography.

Each result represents mean \pm S.D. of six rats.

and osseous region in OVX-mediated osteoporosis. Wronski et al. reported previously that loss of bone in OVX rats was usually earlier and more substantial in areas of cancellous bone than cortical bone ${ }^{5}$. Our results were partly in line with those they reported.

Generally, most studies on evaluating the osteoporosis have been performed using traditional methods such as the evaluation of ash weight (BMC) and histomorphometry. These techniques are well established and useful for the determination of bone mass and bone quality. However, the techniques are labor-intensive and are not performed longitudinally without killing a relative large number of animals at each time point. On the other hand, dual-energy X-ray absorptiometry (DXA) method is a useful tool for estimating the effect on theraphy for osteoporosis in animals and humans ${ }^{23), 24)}$. However, DXA is difficult to measure the BMD (bone mineral density) of the cortical and trabecular bone separately. In the pre- 
sent study, we have developed a new method for the simultaneous determination of bone density by $\beta$-ray radiography. In the validation results, it was established that the precision of the assay fulfilled the aims we proposed. Although the assay conditions of our method were not compared to other conventional methods, there was a statistically significant difference between the OVX rat group and the sham rat group in the femoral and vertebral trabecular bone density. Therefore, the $\beta$-ray radiography yielded results that were nearly identical to those of conventional methods and provided valid results regarding the quantitative assay of bone density. In addition, it is unnecessary for the $\beta$-ray radiography method we developed to prepare any other equipment except radiation source, because we employed almost the same equipments as QWBA system's. It provided a simple, sensitive and reliable technique for determining the bone density of many samples simultaneously. We believe that this advantage will undoubtedly lead to further promising research applications in osteoporosis.

In the current study, $\beta$-ray radiography using ${ }^{147} \mathrm{Pm}$ radiation source enabled simultaneous measurement of bone densities in some osseous regions. The radioisotope used as a radiation source must have a moderate $\mathrm{E}_{\max }$ and emit only $\beta$ particles. ${ }^{147} \mathrm{Pm}$ possesses a moderate half-life (2.623 y) and an adequate energy as $\beta$ particles emission $\left(\mathrm{E}_{\max }, 0.225 \mathrm{MeV}\right)$. On the other hand, ${ }^{204} \mathrm{Tl}\left(\mathrm{E}_{\max }, 0.763 \mathrm{MeV}\right.$ ) emits $\beta$ particles having a rather high energy, giving a flat image lacking in contrast. Under these situations, ${ }^{147} \mathrm{Pm}$ is the most favorable radioisotope to use as a radiation source for $\beta$-ray radiography. However, this particle is of little advantage to obtain a radiation source commercially.
Although, the energy of $\beta$ particles emitted from ${ }^{14} \mathrm{C}\left(\mathrm{E}_{\max }, 0.156 \mathrm{MeV}\right)$ is relatively lower than ${ }^{147} \mathrm{Pm}$, a planar radiation source of this nuclide is able to obtain commercially. Taking these into consideration, further studies are required to clarify the effectiveness of $\beta$-ray radiography using ${ }^{14} \mathrm{C}$ as an alternative to ${ }^{147} \mathrm{Pm}$ radiation source.

\section{References}

1) Riggs, B. L. and Melton, L. J., The worldwide problem of osteoporosis: insights afforded by epidemiology, Bone, 17, 505-511 (1995)

2) Kavuncu, V., Sahin, S., Baydas, G., Ilhan, N., Ozercan, I., Yasar, A., Pekkutucu, I. and Ozercan, R., A comparison of estrogen and two different doses of calicitonin in ovariectomized rats, Yonsei Med. J., 44, 508-516 (2003)

3) Kalu, D. N., The ovariectomized rat model of postmenopausal bone loss, Bone Miner., 15, 175192(1991)

4) Frost, H. M. and Jee, W. S., On the rat model of human osteopenias and osteoporoses, Bone Miner., 18, 227-236 (1992)

5) Wronski, T. J., Cintron, M. and Dann, L. M., Temporal relationship between bone loss and bone turnover in ovariectomized rats, Calcif. Tissue Int., 43, 179-183 (1988)

6) Schmidt, I. U., Walkley, G. K. and Turner, R. T., Effects of estrogen and progesterone on tibia histomorphometry in growing rats, Calcif. Tissue Int., 67, 47-52 (2000)

7) Mochizuki, K. and Inoue, T., Effect of salmon calcitonin on experimental osteoporosis induced by ovariectomy and low-calcium diet in the rat, $J$. Bone Miner. Metab., 18, 194-207 (2000)

8) Uchiyama, Y., Higuchi, Y., Takeda, S., Masaki, T., Shiraishi, A. and Sato, K., ED-71, a vitamin D ana$\log$, is a more potent inhibitor of bone resorption than alfacalcidol in an estrogen-deficient rat model of osteoporosis, Bone, 30, 582-588 (2002)

9) Ulberg, S., Studies on the distribution and fate of 35S-labeled benzylpenicillin in the body, Acta Radiol., 118, 1-110 (Stockholm) Supplement(1954) 
10) Amemiya, Y. and Miyahara, I., Imaging plate illuminates many fields, Nature, 336, 89-90 (1988)

11) Baba, S., Kimata, H., Haruki, S. and Shinohara, Y., Determination of carbon 14 in microplates by radioluminography, Appl. Radiat. Isot., 44, 1011-1014 (1993)

12) Nakajima, E., Radioluminography, a new method for quantitative autoradiography in drug metabolism studies, RADIOISOTOPES, 42, 228-236 (1993)

13) Shigematsu, A., Aihara, M., Motoji, N., Hamai, Y., Asaumi, M., Iwai, S., Ogawa, M. and Miura, K., Proposition for assessment of quantitative wholebody autoradiography, Exp. Mol. Pathol ., 67, 75-90 (1999)

14) Richter, W. F., Starke, V. and Whitby, B., The distribution pattern of radioactivity across different tissues in quantitative whole-body autoradiography (QWBA) studies, Eur. J. Pharm. Sci., 28, 155165 (2006)

15) Baba, S., Development of tracer method in the drug evaluation study, Yakugaku Zasshi, 115, 170188(1995)

16) Baba, S., Kimata, H. and Matsuzawa, T., $\beta$-ray photography of lyophilized animal sections, Appl. Radiat. Isot., 48, 953-957 (1997)

17) Omi, N. and Esawa, I., Techniques for inducing osteoporosis in animals, J. Clin. Exp. Med., 165, 577-580 (1993)

18) Heaney, R. P., Recker, R. R. and Saville, P. D., Menopausal changes in bone remodeling, J. Lab.
Clin. Med., 92, 964-970(1978)

19) Heaney, R. P., Recker, R. R., Stegman, M. R. and Moy, A. J., Calcium absorption in women: relationships to calcium intake, estrogen status, and age, J. Bone Miner. Res., 4, 469-474 (1989)

20) Thomas, M. L. and Ibarra, M. J., Effects of ovariectomy on duodenal calcium transport in the rat: altered ability to adapt to low calcium diet, Proc. Soc. Exp. Bio. Med., 185, 84-88(1987)

21) Kalu, D. N. and Orhii, P. B., Calcium absorption and bone loss in ovariectomized rats fed varing levels of dietary calcium, Calcif. Tissue Int., 65, 7377 (1999)

22) Kobayashi, M., Hara, K. and Akiyama, Y., Effect of vitamin $\mathrm{K}_{2}$ (menatetrenone) on calcium balance in ovariectomized rats, Jpn. J. Pharmacol., 88, 55-61 (2002)

23) Rosen, H. N., Tolin, S., Balena, R., Middlebrooks, V. L., Beamer, W. G., Donohue, L. R., Rosen, C., Turner, A., Holick, M. and Greenspan, S. L., Differentiating between orchiedectomized rats and controls using measurements of trabecular bone density: a comparison among DXA, histomorphometry, and peripheral quantitative computerized tomography, Calcif. Tissue Int., 57, 3539 (1995)

24) Sandstedt, J., Tornell, J., Norjavarra, E., Isaksson, O. G. and Ohlsson, C., Elevated levels of growth hormone increase bone mineral content in normal young mice, but not in ovariectomized mice, Endocrinology, 137, 3368-3374(1996) 
要旨

\title{
オートラジオグラフィによる骨粗鬆症モデルラットの骨密度測定
}

藤野秀樹, 朝原庸光*, 木全秀樹**, 立石 満*, 小出高志 $* *$, 馬場茂雄 $* * * *$

\author{
早稲田大学大学院 先進理工学研究科 \\ 367-0035＼cjkstart埼玉県本庄市西富田大久保山 1011-3 \\ *株式会社ネモトサイエンス つくば研究所 \\ 300-2521 茨城県常総市大生郷町 6136-4 \\ $* *$ 興和株式会社 東京創薬研究所 \\ 189-0022 東京都東村山市野口町 2-17-43 \\ $* * *$ 東京薬科大学 薬学部 \\ 192-0392 東京都八王子市堀之内 1432-1
}

$50 \mu \mathrm{m}$ 厚に薄切した全身切片を ${ }^{147} \mathrm{Pm}$ 面線源及びイメージングプレートと共にコンタクトし， BAS システムによるラジオルミノグラフィー法にて骨密度を評価した。アルミニウムを用いた検 量線は広い密度範囲で輝尽発光值との良好な直線性を示し $\left(R^{2} \geqq 0.999\right)$, かつ良好な再現性を示し た $(\mathrm{CV} \leqq 3.7 \%)$ 。更に骨粗鬆症モデルである卵巣摘出（OVX）ラットを作成し，大腿骨，寛骨及 び金柱の骨密度を擬似手術（Sham）群と共に評価した。OVX 群は大腿骨の皮質骨部並びに海綿 骨部において有意な骨密度低下を示した。しかしながら, 大腿骨の骨髄部では sham 群との密度変 化は認められなかった。一方, 春柱において骨全体では骨密度の変化は認められなかったが，海綿 骨では有意な骨密度低下を示した。これらの成績より，本法はラジオルミノグラフィーとして骨密 度を評価することが可能であると考えられた。 